\title{
CONCEITOS, NORMAS E NÚMEROS: UMA INTRODUÇÃO À EDUCAÇÃO ESCOLAR QUILOMBOLA
}

\author{
JOSÉ MAURÍCIO ARRUTI
}

\begin{abstract}
Resumo
Este texto tem por objetivo introduzir o leitor na temática da educação quilombola por meio da apresentação dos seus conceitos básicos, das políticas públicas a eles relacionadas e, finalmente, dos números oficiais relativos à alfabetização da população quilombola e às escolas situadas em territórios quilombolas. No trato dos números, estabelecemos uma primeira comparação com as categorias de "educação escolar indígena" e de "escolas rurais". Trata-se de uma aproximação do tema por meio da definição dos seus contornos mais largos, indo do conceitual ao quantitativo, passando pelo normativo.
\end{abstract}

Palavras-chave: Educação quilombola. Políticas públicas. Escola.

\section{CONCEPTS, NORMS AND NUMBERS: AN INTRODUCTION TO QUILOMBOLA SCHOOL EDUCATION}

\begin{abstract}
Absctract
This paper aims to introduce the reader on the subject of "quilombo education" (education for rural black communities) through the presentation of it's basic concepts, the public policies related to them and the official statistics concerning the educational situation of quilombo communities (literacy and number of schools existent). In dealing with numbers, we established a first comparison with two other statistical categories: "indigenous education" and "rural schools". It is a themed
\end{abstract}

1 Professor do Departamento de Antropologia da Universidade Estadual de Campinas (Unicamp). Devo um agradecimento especial à Prof. ${ }^{a}$ Joice Melo Vieira, do Núcleo de Estudos de População Elza Berquó (NEPO/UNICAMP), que generosamente fez a revisão e a atualização das tabelas e dos gráficos baseados no Censo Escolar (INEP). 
approach by defining their broader contours, ranging from conceptual to quantitative, through normative.

Keywords: Quilombo education. Public policies. School.

\section{CONCEPTOS, NORMAS Y CIFRAS: UNA INTRODUCCIÓN A LA EDUCACIÓN ESCOLAR PARA QUILOMBOS}

\section{Resumen}

Este texto introduce el tema de la "educación de quilombos" ("palenques" o comunidades negras campesinas) a través de la presentación de sus conceptos básicos, de las políticas públicas relacionadas con ellos y, por último, de las cifras oficiales (sobre alfabetización y número de escuelas). Al tratar con los números, se estableció también una primera comparación con las categorías de "educación indígena" y "escuelas rurales". Se trata de una definición de los contornos más amplios de lo tema, que va desde la abordaje conceptual a la cuantitativa, a través de normativa.

Palabras clave: Educación de quilombos. Políticas públicas. Escuelas.

\section{Introdução}

Este texto tem por objetivo introduzir o leitor na temática da educação quilombola por meio da apresentação dos seus conceitos básicos, das políticas públicas a eles relacionadas e, finalmente, dos números oficiais relativos à alfabetização da população quilombola e às escolas situadas em territórios quilombolas. No trato dos números, estabelecemos uma primeira comparação com as categorias de "educação escolar indígena" e de "escolas rurais", buscando entender a relação entre elas. Trata-se de uma aproximação do tema por meio da definição dos seus contornos mais largos, indo do conceitual ao quantitativo, passando pelo normativo.

Hoje contamos com interessantes descrições etnográficas de situações escolares em comunidades quilombolas, assim como (em número muito menor) de processos de construção de políticas públicas estaduais para a educação quilombola. Uma resenha desses trabalhos permitiria uma introdução ao tema mais próximo da experiência dos atores sociais, ao mesmo tempo em que nos ofereceria o retrato do que pode ser pensado como um campo de estudos em formação. A opção por nos aproximarmos do tema por meio dos conceitos, normas e 
números oficiais responde, porém, para além de razões práticas, a uma intenção analítica: evidenciar que nosso objeto de interesse, a educação escolar quilombola, não é nem uma realidade da qual possamos propor um retrato preciso, nem uma proposta pedagógica específica ou uma política pública definida. Os conceitos ainda estão em litígio: ou ainda não foram incorporados nas contagens oficiais ou, quando o foram, o seu registro é impreciso, já que suas definições ainda se encontram em ajuste e em disseminação entre os administradores públicos. Enfim, repetindo algo que já disse sobre o próprio conceito de quilombo, a educação escolar quilombola é também um objeto em construção. Este texto tem por objetivo, assim, iluminar algumas das dimensões dessa construção.

\section{Conceitos}

Nas raras vezes em que o termo quilombo é incluído no currículo do ensino médio ou fundamental, ou mesmo na historiografia oferecida aos não especialistas, o termo denota uma instituição histórica excepcional e estreitamente vinculada à fuga da escravidão, portanto, difícil de ser transposta para o presente, muito menos no volume em que se apresenta hoje. Parece útil, portanto, começarmos por uma breve exposição sobre a história do conceito.

\subsection{Quilombo: de categoria colonial a movimento social}

A primeira definição de quilombo, no Brasil, dá-se no corpo das legislações colonial e imperial, sob uma forma calculadamente vaga e ampla, que permitia que uma mesma norma de caráter repressivo abarcasse o maior número de situações de interesse. Na Colônia, bastava que cinco escravos fugidos se reunissem, ocupassem ranchos permanentes e possuíssem um pilão para caracterizar a formação de um quilombo. No Império, porém, esses critérios ficaram ainda mais largos, de forma que a reunião de três escravos fugidos, mesmo que não formassem ranchos permanentes, poderia ser considerado um quilombo. $\mathrm{O}$ arco de situações concretas que tal definição cobria está apenas começando a ser revelado por uma historiografia recente (que nos remete ao início da década de 1990) e de grande capacidade de renovação dos paradigmas anteriores.

Ao lado de Palmares, que foi tomado como modelo ideal de quilombo, verdadeiro "Estado Africano no Brasil", composto de milhares de pessoas organizadas em diferentes aldeias, munidas de exército e realizando uma oposição 
sistemática à ordem vigente (CARNEIRO, 1988), vão emergindo situações tão diferentes quanto as comunidades de pequenos produtores de alimentos que habitavam a periferia das cidades e realizavam comércio sistemático com seus comerciantes, os pequenos grupos nômades que viviam do assalto às senzalas, ou ainda comunidades e extrativistas (REIS; GOMES, 1996). Nesse contexto, também destacam-se as Casas de Angu ou Zungús, que ocupavam o próprio centro da cidade imperial em pleno século XIX (SOARES, 1998). Também chamados de "casas de quilombo", estes espaços urbanos serviam para o encontro de escravos de ganho ou fugidos, como restaurantes populares, locais de descanso, religião e lazer, assim como espaço de troca de mercadorias - parte delas roubadas. Tais formações urbanas nos servem de exemplo especialmente útil da plasticidade do conceito histórico de quilombo: apesar de percebidas como foco de desordem em pleno centro da capital imperial e vigiadas ou assaltadas ao longo de todo o século XIX, elas eram também relativamente toleradas pelas classes dominantes devido ao seu papel na manutenção do precário equilíbrio daquela complexa ordem urbana, o que podia acontecer também no espaço rural.

Com a instauração da República, o termo "quilombo" não desapareceu, mas sofreu uma radical ressemantização. Se as alterações na legislação levaram a redefinições da noção de quilombo, o que acontece depois da saída desta noção da legislação não é mais relativo às definições, mas às significações: por não ter mais uma função prática de natureza legal, a palavra "quilombo" passa a ser submetida a usos variados, que, tendo em vista a sua denotação original, atribuem-lhe diferentes conotações. Como a relação entre denotação e conotação não é fixa e imutável, nem de mão única, tal multiplicação de conotações teve impacto sobre o processo político-legislativo que veio a fixar uma nova definição legal para o termo. Como veremos a seguir, ao deixar de ser um termo acusatório e criminalizante (na legislação colonial e imperial), ele assume, ao longo da República, conotações positivas, principalmente no plano das metáforas políticas, até que, voltando a constar das normas legais (Constituição Federal de 1988), o termo torna-se objeto de uma longa controvérsia, ainda inconclusa. Vejamos como isso aconteceu. ${ }^{2}$

Na introdução do seu livro Quilombo de Palmares - primeira obra histórica publicada sobre o tema em 1958 -, Édson Carneiro fez uma dedicatória a Astrogildo Pereira que pode ser vista como primeiro momento desse processo de ressemantização. Carneiro homenageava Astrogildo Pereira como o primeiro a propor, ainda

2 Para uma exposição mais detalhada e extensa desse processo, consultar Arruti (2008). 
em 1929, nas páginas do jornal do Partido Comunista, uma interpretação classista da luta quilombola (OLIVEIRA, 1988). Pensado desta forma, o quilombo deixava de ser uma formação histórica definida pelos critérios da legislação repressiva colonial e imperial para ser reinterpretada como um precedente da luta social contra o capital e a dominação das elites agrárias. Tal interpretação ganharia estabilidade nos trabalhos de fins dos anos 1950, quando a perspectiva marxista seria adotada como uma das principais matrizes explicativas da historiografia e das ciências sociais brasileiras (REIS; GOMES, 1996): ao mesmo tempo em que se consolidava um tipo de interpretação sociológica da história do negro no Brasil, que tinha por motor a crítica à ideologia da democracia racial (GUIMARÃES, 2002), os trabalhos históricos sobre escravidão passavam a enfatizar a agência escrava, contexto no qual os quilombos passam a ser vistos como expressão histórica de uma resistência política popular. ${ }^{3}$

Tributário dessa conotação positiva do quilombo, o movimento negro o elegeu, nas suas manifestações ao longo dos anos $1970,{ }^{4}$ como ícone da "resistência negra". Com isso, o dia 20 de novembro (data em que se registra a dramática morte do líder político e militar negro Zumbi dos Palmares) é proposto como data alternativa ao treze de maio (no qual o destaque é dado ao ato formal e oficial de assinatura da Lei Áurea pela Princesa Isabel), da mesma forma que a demanda por inclusão da história do negro nos livros didáticos tem no quilombo de Palmares um dos seus principais assuntos (SILVEIRA, 1997).

O ponto culminante desse processo de ressignificação é o livro O Quilombismo, de Abdias do Nascimento (1980), no qual se busca dar a forma de uma tese "histórico-humanista" às apropriações contemporâneas da figura histórica do quilombo. Para Nascimento, os diferentes movimentos sociais de resistência física e cultural da população negra, que ganharam forma não só de grupos fugidos para o interior das matas na época da escravidão, mas também, em um sentido bastante ampliado, de todo e qualquer grupo apenas tolerado pela ordem

3 As análises de Clóvis Moura (1972), por exemplo, dão destaque às táticas de luta e de fuga utilizadas, associadas ao modelo das "guerras-de-guerrilha", como na literatura contemporânea sobre as revoluções e sublevações socialistas na América Latina e Central. Como diria Darcy Ribeiro, em seu estilo direto e literário, no texto de orelha do livro de Décio Freitas (1990, Palmares seria um exemplo desse desafio que a história brasileira apresentou às classes oprimidas: desencadear a revolução socialista que, apesar de necessária, fracassou por ser prematura.

4 Apesar dessa reapropriação vir desde os anos de 1950, com o jornal negro O Quilombo, de Abdias do Nascimento, ela só ganharia o atual sentido diante do movimento negro a partir de 1971, quando da criação do Grupo Palmares por um pequeno grupo de militantes de Porto Alegre, no Rio Grande do Sul (SILVEIRA, 1997). 
dominante em função de suas declaradas finalidades religiosas, recreativas, beneficentes, esportivas ,etc., deveriam ser percebidos como parte de um mesmo fenômeno social, o "quilombismo" (NASCIMENTO, 1980, p. 263). De fato, daí em diante multiplicaram-se os usos desta interpretação do quilombo nas mais variadas manifestações populares, como a música, o carnaval, a literatura e o cinema (HASENBALG, 1992). É basicamente esse contexto que explica a proposição de um artigo, na Constituição Federal de 1988, que contemplava o termo, ainda que sem lhe dar qualquer definição substantiva: "Aos remanescentes das comunidades dos quilombos que estejam ocupando suas terras é reconhecida a propriedade definitiva, devendo o Estado emitir-lhes os títulos respectivos (BRASIL, 1988).

Nós podemos considerar esse percurso como uma primeira linha explicativa da ressemantização do termo quilombo, mas esta não estaria completa se não viesse a se cruzar e sobrepor com um segundo percurso de apropriações do termo, que tem origem no campo da militância pela reforma agrária e nos estudos sociológicos sobre o direito camponês, tendo por foco as regras e padrões específicos de transmissão, controle e acesso à terra por parte de comunidades negras rurais.

O movimento camponês havia tentado fazer com que a Constituição de 1988 avançasse não só na direção de mecanismos gerais de reforma agrária, mas também no reconhecimento de modalidades específicas de direito à terra, fundamentais para a manutenção dos modelos de vida tradicionais encontrados nas regiões estudadas. $\mathrm{O}$ fracasso total dessa tentativa, porém, levou a que, alguns poucos anos depois da homologação da Constituição, o artigo relativo aos "remanescentes de quilombos" figurasse aos olhos dessa militância e de suas assessorias (sociólogos, antropólogos e juristas) como uma alternativa viável às suas demandas, contornando o malogro do Plano Nacional de Reforma Agrária (PNRA) ${ }^{5}$ em fazer o ordenamento jurídico nacional reconhecer a legitimidade das modalidades de uso comum da terra.

Essa conexão foi viabilizada pelo fato de os estudos sobre tais formações camponesas se realizarem justamente em uma região marcada por forte presença de um campesinato negro, onde também foram realizados os primeiros encontros estaduais e regionais de comunidades negras rurais: no Pará, desde 1985, e no

5 O PNRA foi a experiência de institucionalização da luta pela implementação da reforma agrária no país, durante a chamada Nova República, entre 1986 e 1988. O Plano Nacional foi acompanhado de Planos Regionais e de um forte investimento na reforma dos órgãos do setor, incluindo o Instituto Nacional de Colonização e Reforma Agrária (Incra), mas que acabou não conseguindo lograr mudanças no aparato jurídico legal, necessários à sua realização. A Constituinte foi, por isso, palco de grandes disputas por tais mudanças, as quais acabaram não vingando. 
Maranhão desde 1986. O objetivo desses encontros era mapear tais comunidades, levantar suas manifestações culturais, religiosidade e memória oral e investigar suas formas de uso e posse da terra. Tais eventos foram o ponto de partida para novos encontros estaduais e microrregionais realizados ao longo dos anos seguintes, assim como para a organização de várias entidades do movimento negro nos municípios do interior (CCN/SMDDH, 1998), também pautados pela imagem do quilombo. ${ }^{6}$ Esse novo agenciamento do quilombo implicou, por sua vez, em uma nova ressemantização: dos significados que lhe eram atribuídos pelo movimento negro das grandes capitais para os significados que ganhava no contexto da militância agrária do movimento negro das capitais periféricas - onde a relação com a terra e com territórios coletivos passou a ser central. Desde então, essa associação entre quilombo e território é reivindicada em diversos textos de reflexão e de sistematização jurídica.

Diante dessas questões, os antropólogos que já vinham trabalhando com grupos negros rurais não só no Maranhão e no Pará, mas também em Goiás, em São Paulo, no Rio de Janeiro e em Santa Catarina, respaldados na experiência com a questão indígena, propuseram uma nova definição para o termo. Segundo a Associação Brasileira de Antropologia (ABA, 1994), a categoria "remanescentes de quilombos" deve compreender todos os grupos que desenvolveram práticas de resistência na manutenção e na reprodução de seus modos de vida característicos em um determinado lugar, cuja identidade se define por uma referência histórica comum, construída a partir de vivências e de valores partilhados. Nesse sentido, eles se constituem como "grupos étnicos", isto é, um tipo organizacional que confere pertencimento através de normas e meios empregados para indicar afiliação ou exclusão, cuja territorialidade é caracterizada pelo "uso comum", pela "sazonalidade das atividades agrícolas, extrativistas e outras e por uma ocupação do espaço que teria por base os laços de parentesco e vizinhança, assentados em relações de solidariedade e reciprocidade" (ABA, 1997 [1994], p. 81-82).

6 Apesar disso e de estes encontros terem em vista também a elaboração de emendas populares à constituinte, não houve entre eles e os propositores do artigo 68 (ADCT/CF-88) qualquer colaboração efetiva. A independência entre essa mobilização e aquela que resultaria na proposição do Artigo 68 (BRASIL, 1988) é notável. Um dos responsáveis pelo levantamento de agrupamentos negros rurais no interior do estado do Maranhão (entre os quais já eram identificadas diversas comunidades originadas de antigos mocambos e quilombos), Ivo Fonseca, chegou a ser consultado por assessores da deputada Benedita da Silva à época da introdução do artigo sobre quilombos na Carta, "mas foi uma coisa muito de repente, eu mesmo não tinha nenhuma discussão preparada para isso" (Entrevista com Ivo Fonseca, Belo Horizonte, novembro de 2000, citado em Arruti, 2008) . 
Acompanhando essa interpretação, o Ministério Público Federal reconheceu a legitimidade e a legalidade do reconhecimento e da proteção dos direitos - em primeiro lugar territoriais - dessas comunidades. Os argumentos levantados passam pela preservação da cultura e da identidade destas comunidades, pensadas enquanto um dos grupos étnicos formadores da sociedade brasileira. Isso permitiu que um grande número de comunidades negras rurais (mais tarde, também algumas urbanas) passasse a reivindicar a regularização de suas terras de ocupação tradicional, além de políticas públicas. Tais políticas, de início, implicavam apenas na extensão das políticas universais (ou as focadas na pobreza), revelando o quanto aquelas comunidades se mantinham excluídas das ações do Estado. Mas, em um momento seguinte, a demanda passou a ser por políticas específicas, que respeitem e se adequem às particularidades históricas, sociológicas e culturais dessas comunidades. Tem origem, assim, um movimento social novo, o movimento quilombola, que rapidamente passou a se estender sobre um número ainda indefinido de comunidades situadas por todo território nacional. Nesse sentido, se a ressemantização do quilombo no vocabulário político, jurídico e administrativo nacional tanto foi provocado por sua ressemantização no vocabulário das comunidades negras situadas principalmente ao Norte e ao Nordeste do país, ele também acabou por provocar tal ressemantização - ou a sua simples introdução - em um número muito maior de comunidades negras por todo o território nacional. Ou seja, muitas dessas lutas, que vinham sendo travadas sob outras categorias - como a de posseiros, trabalhadores rurais, camponeses, agregados, etc. - foram redefinidas a partir da nova categoria jurídica disponível.

\subsection{Educação quilombola: delineando uma política}

Para situarmos o processo de definição de uma política que tem em vista a ideia de uma educação quilombola, é preciso fazer referência ainda a outra história de debates e a outros precedentes normativos, cuja origem podemos situar na Lei de Diretrizes e Bases da Educação (Lei no 9.394/1996). A reforma educacional iniciada com ela trouxe mudanças importantes para a abordagem da cultura na escola e da escola, ao abri-la para uma revisão daquilo que os seus livros didáticos apresentam como a "formação do povo brasileiro", que já não pode mais contornar o tema das relações étnico-raciais: "o ensino da História do Brasil deve levar em conta as contribuições das diferentes culturas e etnias para a formação do povo brasileiro, especialmente das matrizes indígena, africana e europeia" (BRASIL, 1996). 
Esse movimento foi completado quando, em resposta ao terceiro ciclo de reformas promovidas pela Convenção sobre a Eliminação de Todas as Formas de Discriminação Racial (1969), o Brasil incorporou a diretriz que destacava o papel da educação para a garantia do respeito aos direitos, incluindo a análise das causas e das consequências do racismo. Assim, em 2003, o Congresso Nacional alterou a Lei de Diretrizes e Bases para estabelecer a obrigatoriedade da inclusão, no currículo oficial das redes de ensino, públicas e particulares, da temática "História e Cultura Afro-Brasileira" (Lei no 10.639), ao mesmo tempo em que o Governo Federal criava duas secretarias estratégicas para a formulação e a implementação de políticas de ações afirmativas relativas à população negra do país, a Secretaria Especial de Políticas de Promoção da Igualdade Racial (SEPPIR, 2003) e a Secretaria de Educação Continuada, Alfabetização e Diversidade (SECAD, 2004). Enquanto a primeira gerou e coordenou o Programa Brasil Quilombola (PBQ), a segunda teve como tarefa principal a implementação da Lei $n^{\circ} 10.639 / 2003$. Foi nesse contexto institucional no qual, pela primeira vez, discutiu-se, de forma ampla e institucionalmente amparada, a extensa pauta relativa às populações negras no país, tornando possível sobrepor as questões educacionais às ações previstas para um recorte populacional negro cuja principal demanda, até então, era o acesso à terra.

Uma referência explícita às comunidades quilombolas, porém, só viria a constar no texto das Diretrizes Curriculares Nacionais para a Educação das Relações Étnico-Raciais e para o Ensino de História e Cultura Afro-Brasileira e Africana (BRASIL, 2004). Porém, nesse caso, as Diretrizes concebiam as comunidades negras mais como objeto de interesse do que como público específico. A inflexão final só ocorreria em 2006, quando da publicação, pela SECAD, do Guia de orientações e ações para implementação da Lei 10.639/2003, no qual a educação quilombola consta, finalmente, como um item específico, relativo tanto às escolas situadas em áreas de remanescentes de quilombos, quanto às escolas que atendem quilombolas. A consolidação de uma lista com as principais ações para a educação em áreas de remanescentes de quilombos seria publicada dez anos depois, como parte do Plano Nacional de Implementação das Diretrizes Curriculares nacionais para a Educação das Relações Étnico-raciais e para o Ensino de História e Cultura Afro-brasileira e Africana (BRASIL, 2013). ${ }^{7}$

7 As ações eram: a) apoiar a capacitação de gestores locais; b) mapear as condições estruturais e as práticas pedagógicas das escolas; c) garantir o direito à educação básica para crianças e adolescentes; d) ampliar e melhorar a rede física escolar por meio de construção, ampliação, reforma e equipamento de unidades escolares; e) promover formação continuada de professores da edu- 
Depois de um ano de conferências municipais e estaduais, representantes das secretarias do Ministério da Educação, da Câmara, do Senado, do Conselho Nacional de Educação, das entidades dos dirigentes estaduais, municipais e federais da educação e de uma grande variedade de entidades que atuam direta ou indiretamente na área da educação produziram, no âmbito da Conferência Nacional de Educação (CONAE, 2010), um documento que tinha como uma das novidades mais notáveis a introdução de um capítulo sobre educação quilombola. Nele, estava previsto o direito à preservação das manifestações culturais dessas comunidades, da sustentabilidade de seu território tradicional, da observação de uma alimentação e de uma infraestrutura escolar que respeitem sua cultura e sua relação com o meio ambiente, assim como a formação diferenciada dos professores destas escolas, a criação de um programa de licenciatura quilombola, a elaboração de materiais didático-pedagógicos específicos e, no campo da gestão, a adoção de mecanismos que garantam a participação de representantes quilombolas na composição dos conselhos referentes à educação (CONAE, 2010).

Essa pauta gerou a formação de um Grupo de Trabalho para Educação Quilombola, no Conselho Nacional de Educação (CNE), destinado a elaborar as Diretrizes Curriculares Nacionais para a Educação Escolar Quilombola e a realizar o I Seminário Nacional de Educação Quilombola, em novembro de 2010, que contou com a participação de 240 pessoas - entre elas, gestores das secretarias estaduais e municipais de Educação, gestores e professores de escolas quilombolas, professores e pesquisadores da educação para as relações étnico-raciais e lideranças quilombolas. Abriu-se, assim, espaço para que o reconhecimento da especificidade e dos direitos quilombolas ultrapassasse, também no campo da educação, a simples consideração destes grupos como "os mais pobres dos mais pobres". Ultrapassava-se, assim, o limite entre as chamadas "políticas de reconhecimento", ou seja, o conjunto de ações públicas elaboradas em atenção às especificidades das comunidades quilombolas, e as "políticas de redistribuição", ou seja, aquelas formuladas como simples extensão, como repasse diferenciado de recursos ou como reserva de uma cota especial no interior de políticas universais, cujo objetivo é corrigir uma situação de exclusão. ${ }^{8}$

cação básica; f) editar e distribuir materiais didáticos, considerando seu processo o histórico e patrimônio cultural; g) produzir materiais didáticos específicos para EJA; h) incentivar a relação escola/comunidade; e i) aumentar a oferta de ensino médio.

8 Para o debate seminal sobre reconhecimento e redistribuição, ver Frazer (1997). Para uma atualização deste debate, com relação especificamente ao tema dos quilombos no Brasil, ver Figueiredo (2011). 
Não se trata de opor uma política a outra (FRASER, 1997), mas de identificar, de um lado e de outro, princípios de ação distintos, que respondem a necessidades distintas, não redutíveis umas às outras. Ainda que exista um longo percurso até a correção da situação mais elementar de acesso à educação por parte das comunidades quilombolas, como veremos adiante, a elaboração de um Plano Nacional de Educação Quilombola aponta para uma abordagem qualitativa e não apenas quantitativa da política destinada a essa correção, tendo em vista a diferença e não apenas a desigualdade no trato dessas comunidades. O que tal política exige dos poderes públicos é que eles reconheçam não apenas que o preconceito racial implicou em um agravante da exploração da população pobre e rural, mas também que tais grupos se distinguem por formas próprias de organização social e cultural. Ao lado de uma política fundiária diferenciada surge, assim, a proposição de uma educação diferenciada, que ultrapasse uma visão do outro que o reduz ao pobre, ao deficitário, ao dominado. É nesse sentido que a educação escolar quilombola passou a ser definida como uma nova modalidade de educação, nos seguintes termos:

Art. 41. A Educação Escolar Quilombola é desenvolvida em unidades educacionais inscritas em suas terras e cultura, requerendo pedagogia própria em respeito à especificidade étnico-cultural de cada comunidade e formação específica de seu quadro docente, observados os princípios constitucionais, a base nacional comum e os princípios que orientam a Educação Básica brasileira.

Parágrafo único. Na estruturação e no funcionamento das escolas quilombolas, bem com nas demais, deve ser reconhecida e valorizada a diversidade cultural (MEC, 2010).

Finalmente, em 2012, foram aprovadas pela Câmara de Educação Básica do Conselho Nacional de Educação, as Diretrizes Curriculares Nacionais para a Educação Escolar Quilombola (MEC, 2012), que devem orientar os sistemas de ensino para que eles possam colocar em prática a Educação Escolar Quilombola em diálogo com a realidade sociocultural e política das comunidades e dos movimentos quilombola. ${ }^{9}$

9 As Diretrizes Curriculares Nacionais para a Educação Escolar Quilombola foram construídas a partir de consultas públicas oficiais no Maranhão, na Bahia e em Brasília, realizadas pelo Conselho Nacional de Educação (CNE)/Ministério da Educação (MEC), assim como de consultas públicas em outros estados a partir de iniciativas locais e autônomas, reivindicadas pelas 
A homologação desses textos, de extensão nacional, produziu impacto relevante em primeiro lugar por padronizarem o vocabulário, os mecanismos legais e institucionais e os recursos disponíveis para o tema, além de impactar o debate social e intra-governamental relativo às "políticas de diversidade", especificamente no Ministério da Cultura (MEC).

Nesse sentido, é importante perceber o paralelismo e a possível influência da promulgação, também no ano de 2010, do Decreto no 7.352 (BRASIL, 2010), que "dispõe sobre a política de educação do campo e o Programa Nacional de Educação na Reforma Agrária - PRONERA”, além de discutir a educação quilombola. Por meio desse decreto, os movimentos sociais do campo buscam reverter duas características fundamentais do sistema educacional brasileiro: a lógica urbana, etnocêntrica e evolucionista, segundo a qual o rural representa a carência e o atraso, e a predominância de políticas públicas generalistas que desconhecem as especificidades de determinadas populações, entre elas a do campo. Com este novo decreto, defende-se a pertinência de uma política educacional diferenciada, cujo objetivo não deve ser mais levar a mesma escola a todos os lugares e populações. Essa necessidade emerge da constatação de que uma das maiores e mais importantes consequências da lógica urbanocêntrica é a formação de uma juventude que perde completamente a empatia com o modo de vida de sua própria família e que, muitas vezes, está pronta para trocar o campo pela periferia urbana. Segundo pensadores como Miguel Arroyo (2008), a proposição de uma educação do campo pretende incorporar, na definição de educação, a importância da terra e do território, da cultura e da identidade dos povos do campo.

Se levarmos a sério tais recomendações, porém, seremos obrigados a reconhecer que existem muito mais modos de se relacionar com a terra do que aqueles previstos sob a categoria de "camponês", "agricultor familiar" e "trabalhador rural", que, em geral, descrevem as populações do campo. Assim, se a crítica que a educação do campo faz às escolas convencionais é pertinente, o modelo que é proposto no seu lugar acaba apresentando também um viés homogeneizante. Isso acontece porque, apesar de sempre se saber da grande parcela de população negra que compóe o campesinato e o proletariado rural brasileiro, isso nunca conferiu particularidade a essa população, seja do ponto de vista da historiografia, da militância social ou das políticas públicas. Além disso, diante da recomendação de se privilegiar o vínculo entre terra, território e escola, é necessário observar

organizações quilombolas e pelos movimentos parceiros. Uma descrição minuciosa dessas consultas é apresentada na dissertação de Noronha (2013). 
que as comunidades quilombolas têm como uma de suas características definidoras justamente as terras de uso comum, o que leva a imaginar a pertinência de um novo formato de escola para essas populações: o uso comum, a memória da escravidão, o racismo institucional a que foram historicamente submetidas e a identidade de negros. Isso acaba ampliando o quadro de questões que deveriam ser contempladas por uma escola do campo dirigida para comunidades quilombolas. É nessa direção que aponta o documento da Conferência Nacional de Educação (CONAE 2010).

\section{Ponderações sobre conceitos e números}

A aproximação dos números relacionados à educação escolar quilombola deve ser cuidadosa. Em primeiro lugar, é preciso considerar que aquilo que genericamente é chamado de "escola quilombola" (inclusive em documentos oficiais) e que, dessa forma, leva-nos a imaginar uma situação escolar diferenciada, na verdade corresponde ao que, no Censo Escolar, é identificado, de forma muito mais prosaica, como "escolas em áreas de quilombo". Ou seja, essas escolas são "quilombolas" apenas na medida em que estão situadas em terras que são assim identificadas. Isso ocorre por uma reclassificação das escolas já existentes - possível depois da introdução desta categoria no censo escolar do Instituto Nacional de Estudos e Pesquisas Educacionais Anísio Teixeira (INEP) em 2004 -, sem que isso implique a existência de qualquer diferenciação na sua forma física, nos métodos pedagógicos, na sua gestão, na composição e formação dos seus professores, nos materiais didáticos utilizados ou mesmo no tipo de atenção dada pelo corpo docente a temas fundamentais nesse contexto, como as relações raciais e a própria questão dos quilombos.

Em segundo lugar, é preciso considerar que as "escolas em áreas de quilombo" podem não receber apenas (e, eventualmente, nem mesmo principalmente) as crianças de tais comunidades, recebendo também crianças de comunidades do entorno. Da mesma forma, escolas situadas fora das áreas de quilombo, mas nas vizinhanças de comunidades quilombolas, podem atender também - e, por vezes, principalmente - as crianças dessas comunidades. Assim, os números de que dispomos não cobrem o número real de estudantes quilombolas, muito menos nos permite estimar a demanda não atendida.

Por fim, a classificação "em área de quilombo" é atribuída ao(à) diretor(a) da escola no momento do preenchimento do censo escolar, o que nos coloca o 
problema de essa classificação não se dar nem por auto-atribuição da comunidade, nem pelo reconhecimento prévio e oficial dessa comunidade e de seu território pelo Estado brasileiro, ${ }^{10}$ mas pelo conhecimento, avaliação, reconhecimento ou mesmo adesão ou oposição deste(a) gestor(a) em relação à classificação étnica, cultural e política da comunidade ou bairro em que a sua escola está situada, o que implica, quase sempre, uma tomada de posição política por parte deste funcionário público. Temos exemplos etnográficos interessantes de como isso produz variações importantes no cômputo geral, seja pela simples negação de que a escola seja quilombola - mesmo quando se trata de uma luta de notoriedade nacional, como acontece no caso da Ilha da Marambaia (Oliveira, 2009) -, seja, ao contrário, quando tal classificação da escola ocorre sem que ela encontre correspondência em uma comunidade auto-identificada ou oficialmente reconhecida quilombola. Vejamos dois exemplos.

Na região do Baixo Sul da Bahia, por exemplo, registramos situações nas quais algumas escolas foram classificadas como "localizadas em área de comunidade quilombola" sem que disso resultasse o processo e os benefícios esperados. A partir de 2005, as comunidades situadas nos municípios de Valença, Cairu, Taperoá, Nilo Peçanha, Ituberá, Igrapiúna, Camamu e Maraú foram certificadas como quilombolas pela Fundação Cultural Palmares (FCP). ${ }^{11}$ Do total de 42 comunidades, dez estão localizadas no município de Camamu, todas certificadas no mesmo ano de 2008. ${ }^{12}$ À primeira vista, esses números sugerem que a região do Baixo Sul da Bahia (com epicentro em Camamu desde 2008) foi, ao menos no período, um importante foco de mobilização quilombola. Na verdade, porém, tais certificações foram expedidas pela FCP com base em solicitação emitidas pelas municipalidades sem que as próprias comunidades fossem consultadas ou mesmo informadas. Isso explica que, ao menos até 2008, a inclusão destas comunidades no livro de certificações da FCP não houvesse garantido qualquer acesso dessas comunidades

10 Aqui é necessário explicar que a Fundação Cultural Palmares, desde a edição do Decreto ${ }^{\circ}$ 4.788 , de 20 de novembro de 2003, assumiu a atribuição de "certificar" as comunidades quilombolas por meio do seu registro em um livro de cadastro nacional. Tal certificação é baseada, principalmente - mas não exclusivamente (para o bem e para o mal) -, na auto-atribuição do grupo. É essa certificação e esse registro que levam à inclusão dessas comunidades na lista das demais políticas públicas que dão atenção diferenciada a tais comunidades, como o Bolsa Família, por exemplo.

11 Em 2005, foram reconhecidas quatro comunidades na região. Em 2006 e em 2007, foram reconhecidas nove e, em 2008, chegou-se ao maior número por ano: quinze. Depois disso, o ritmo diminuiu: cinco em 2009 e apenas quatro entre 2010 e 2013.

12 A lista atualizada das comunidades certificadas pela FCP encontra-se no site da Fundação: http://www.palmares.gov.br. 
a políticas públicas anunciadas pelo governo federal, muito menos ao processo de regularização fundiária. Nesse caso, a classificação como quilombola era parte de uma estratégia da municipalidade para multiplicar recursos, tanto materiais e de acesso imediato, já que tal classificação implica o aumento do valor por aluno destinado à escolas pelo Fundo de Manutenção e Desenvolvimento da Educação Básica e de Valorização dos Profissionais da Educação (FUNDEB), quanto imateriais e de acesso futuro, já que o turismo local passou a ter um atrativo a mais no anúncio da existência das comunidades quilombolas (ARRUTI; CAMPOS, 2008).

Um segundo exemplo, em certa medida oposto ao anterior, vem de Salvador. Ao iniciarmos o estudo dos dados do censo escolar, ainda em 2009, percebemos que mais de $10 \%$ das "escolas quilombolas" do país eram classificadas como "urbanas" e que a quase totalidade delas (71 escolas) estavam localizadas em Salvador (BA). Como as áreas de remanescentes de quilombos são, em sua grande maioria, rurais e como, além disso, não havia registro de comunidades quilombolas urbanas em Salvador, o dado parecia resultar de algum erro de classificação. Em entrevista na Secretaria Municipal de Salvador realizada naquele mesmo ano, porém, descobrimos que a gestão municipal já havia se assustado com os números do Censo Escolar de 2006 e já produzira um diagnóstico daquele que lhes parecia ser o erro no preenchimento do censo. Os funcionários haviam constatado a existência de apenas quatro escolas quilombolas no município, ou seja, quatro escolas situadas em áreas oficialmente reconhecidas como remanescentes de quilombos - todas definidas, segundo os critérios do Instituto Brasileiro de Geografia e Estatística (IBGE), como rurais. Em função, disso a secretaria produziu um pequeno texto de referência para ser distribuído entre os gestores das escolas; mas, ainda assim, no preenchimento do censo seguinte, de 2008, 25 gestores de escolas urbanas continuavam insistindo na autodesignação como quilombola.

Portanto, estávamos diante não exatamente de um "erro" classificatório, mas de uma divergência resultante da forma pela qual o processo de ressemantização do termo quilombo foi operado naquele contexto social, cultural e institucional. Segundo gestores do município e militantes do movimento negro entrevistados, um dos efeitos da forte marca do ideário quilombola na cidade de Salvador foi a produção de um postura militante por parte dos(as) gestores(as) de escolas públicas situadas nos bairros pobres da capital, majoritariamente negros. Nesses bairros, a designação de quilombo foi incorporada como forte expressão identitária, mas de tal forma que, estando absolutamente ajustada ao ideário do "quilombismo" proposto por Abdias do Nascimento (1980), não respondia a qualquer demanda fundiária explícita - do que tem dependido o uso legal do termo. 
Exemplo importante disso é o Fórum de Quilombos Educacionais (FOQUIBA) que, criado em 2001, funciona como uma rede local de cursos pré-vestibulares para jovens negros de Salvador. A própria existência e atuação do FOQUIBA provavelmente alimentaram a identificação dos gestores das escolas locais com a identidade de uma escola quilombola, independentemente do sentido que a Secretaria de Estado da Educação quisesse atribuir ao termo, de forma a ajustá-lo aos usos do MEC/INEP.

Assim, como dizíamos, é preciso uma aproximação cuidadosa das categorias e dos números relacionados à educação escolar quilombola. É sob tal alerta que devemos enfrentar os números apresentados a seguir.

\section{$4 \quad$ Números}

Não há, no Brasil, um levantamento oficial definitivo sobre o número de comunidades quilombolas. Os números do movimento quilombola, que trabalha com estimativas vagas e aproximativas (na casa das cinco mil comunidades), são diferentes dos números da Secretaria de Políticas de Promoção da Igualdade Racial (SEPPIR) e da Fundação Cultural Palmares, que trabalham sobre a soma das comunidades "certificadas" (total de 2.474 segundo a "Lista das CRQs Certificadas até 23-02-2015”), ${ }^{13}$ que, por sua vez, são diferentes dos números do INCRA, que trabalha com diversas totalizações relativas às etapas do processo de regularização fundiária, ${ }^{14}$ entre as quais temos as comunidades com Relatórios Técnicos de Identificação e Delimitação já produzidos (201 comunidades em maio de 2016) e as comunidades já efetivamente tituladas em seus territórios (30

13 Informação disponível em: < http://www.palmares.gov.br/?page_id=88>. Acesso em: 09 maio 2016. Na mesma data, a FCP informava a existência, ainda, de 326 comunidades com pedidos de certificação ainda não atendidos. A emissão da Certidão de Autodefinição tem como base legal a Portaria da FCP no 98/2007 e o Decreto Presidencial nº 4887/2003.

14 O processo começa com a apresentação da Certidão de Registro no Cadastro Geral de Remanescentes de Comunidades de Quilombos, emitida pela Fundação Cultural Palmares, depois do que o INCRA deve elaborar um estudo da área, destinado à confecção do Relatório Técnico de Identificação e Delimitação (RTID) do território. Em seguida há a análise e o julgamento de eventuais contestações e, depois de definitivamente aprovado o relatório, a publicação de uma portaria no Diário Oficial da União. As etapas seguintes correspondem à "desintrusão" (retirada de ocupantes não quilombolas mediante desapropriação e/ou pagamento de indenização) e a demarcação do território. O processo só chega ao fim com a concessão do título de propriedade (coletivo, inalienável e intransferível) à associação quilombola, que deve ser registrado no cartório de imóveis. 
comunidades em maio de 2016). ${ }^{15}$ Além disso, se contar as comunidades é difícil, apurar a sua população é praticamente impossível a partir dos dados oficiais disponíveis: apesar de serem as bases de dados mais completas existentes no país, os censos demográficos não contêm qualquer informação direta sobre territórios e populações quilombolas, já que o IBGE não conta com a categoria "quilombola" como conta com a categoria "indígena" nos seus recenseamentos demográficos.

Para contornar essa limitação, um grupo de pesquisadores interessados em mapear o tema da relação entre diversidade e desigualdade nos censos demográficos nacionais propôs algumas estratégicas metodológicas por meio das quais pudéssemos acessar as informações detalhadas oferecidas pelo Censo Demográfico 2010, ao menos para a população quilombola dos territórios titulados (no caso, 146.926 pessoas, número correspondente à população de 171 territórios). ${ }^{16}$ O tópico a seguir lançará mão dos dados levantados a partir desse exercício para nos aproximarmos da situação da população quilombola, no que diz respeito à escolarização, enquanto, no tópico seguinte, lançaremos mão mais simplesmente das informações disponíveis no Censo Escolar do INEP.

\subsection{Alfabetização quilombola}

A primeira consideração sobre os dados obtidos pela sobreposição entre os setores censitários do Censo Demográfico de 2010 e as terras das comunidades quilombolas tituladas é que, considerando apenas as pessoas que possuem dez anos ou mais de idade, as taxas de alfabetização nos territórios quilombolas (TQ) compulsados são inferiores às encontradas no Brasil, em geral, e nos municípios em que essas mesmas comunidades estão situadas, em particular. Enquanto a porcentagem de alfabetizados com 10 anos ou mais de idade é de 75,6\% nos TQ, ela atinge $91 \%$ no país e $94,3 \%$ nos municípios em questão. Se diferenciarmos os TQ situados em área urbana e os situados em área rural, veremos que a população quilombola rural está em significativa desvantagem. Enquanto, nas áreas rurais, as taxas de alfabetização para os TQ, para o Brasil e para os municípios correspondentes são, respectivamente de $74 \%, 78,7 \%$ e $78,2 \%$, nas áreas urbanas, essas

15 Dados disponíveis em: < http://www.incra.gov.br/quilombola >. Acesso em: 09 maio 2016.

16 Os dados apresentados a seguir foram gerados no âmbito de um processo de pesquisa em rede intitulado "Desigualdades étnico-raciais no Brasil: análise dos povos indígenas e das comunidades quilombolas", que trabalhou com a lista de comunidades tituladas até o ano de 2014. Uma apresentação sucinta do esforço metodológico que sustenta este tópico é apresentada na "Nota metodológica" que acrescentamos ao final deste texto como forma de aliviar a sua leitura. 
porcentagens são de $87,2 \%, 93,2 \%$ e 95,5\% respectivamente. Se, entre a população de 10 anos ou mais de idade, os dados nos apontam para a situação histórica de desvantagem dos jovens e adultos residentes nos territórios quilombolas, o cruzamento de informações sobre a população entre cinco e nove anos é ainda mais relevante para mostrar o quanto tais desigualdades mantêm suas condições de reprodução. Nesta faixa etária, as taxas de alfabetização nos TQ são ainda menores se comparadas às totais do Brasil e dos municípios correspondentes.

Tabela 1 - Distribuição dos alfabetizados (de 5 a 9 anos e de 10 anos ou mais) por localização. Territórios Quilombolas, Brasil e municípios selecionados, 2010

\begin{tabular}{ccccccc}
\hline & \multicolumn{2}{c}{ Territórios Quilombolas } & \multicolumn{2}{c}{ Brasil } & \multicolumn{2}{c}{ Municípios } \\
\cline { 2 - 7 } & $\begin{array}{c}\mathbf{5} \text { a } \mathbf{9} \\
\text { Anos }\end{array}$ & $\begin{array}{c}\mathbf{1 0} \text { anos } \\
\text { ou mais }\end{array}$ & $\begin{array}{c}\mathbf{5} \text { a } \mathbf{9} \\
\text { Anos }\end{array}$ & $\begin{array}{c}\mathbf{1 0} \text { anos } \\
\text { ou mais }\end{array}$ & $\begin{array}{c}\mathbf{5} \text { a } \mathbf{9} \\
\text { anos }\end{array}$ & $\begin{array}{c}\mathbf{1 0} \text { anos } \\
\text { ou mais }\end{array}$ \\
\hline RURAL & $47,1 \%$ & $74,0 \%$ & $55,1 \%$ & $78,7 \%$ & $53,3 \%$ & $78,2 \%$ \\
URBANO & $68,7 \%$ & $87,2 \%$ & $71,6 \%$ & $93,2 \%$ & $74,1 \%$ & $95,5 \%$ \\
Total & $49,4 \%$ & $75,6 \%$ & $68,5 \%$ & $91,0 \%$ & $72,0 \%$ & $94,3 \%$ \\
\hline
\end{tabular}

Fonte: Banco de dados TQ do CEM/CEBRAP e CPEI-NEPO/UNICAMP com base no Censo Demográfico 2010 do IBGE. (Arruti; Dowbor, 2013)

Conforme a Tabela 1, a taxa de alfabetização da população de 5 a 9 anos nos TQ é de apenas 49,5\%, contra 72,0\% nos municípios em que estão localizados e $68,5 \%$ no total nacional. Essas diferenças são ainda mais gritantes se forem comparadas as populações de TQ das áreas urbanas e rurais. Enquanto, nas primeiras, a porcentagem de crianças de 5 a 9 anos alfabetizadas é de 68,7\%, nas segundas, ela não passa de 47,1\% - a taxa mais baixa em comparação, inclusive, com as taxas observadas no Brasil rural $(55,1 \%)$ e nas áreas rurais dos municípios estudados $(53,3 \%)$. Assim, ainda que o problema do atraso escolar subsista em todos os grupos sociais e de idade, em diferentes modalidades de ensino e em diversas localidades geográficas, os dados oficiais apontam para uma situação de maior vulnerabilidade das populações que vivem em domicílios localizados no interior dos territórios quilombolas, mesmo entre as crianças, que possuem maior acesso ao sistema educacional que seus pais e avós tiveram.

A desvantagem da população residente em territórios quilombolas, em comparação com o perfil municipal e nacional, mantém-se também ao considerarmos as taxas de alfabetização apenas das pessoas responsáveis pelo domicílio. Seja no âmbito rural ou urbano, e independentemente do sexo, os responsáveis por domicílio nos TQ possuem menor nível de alfabetização que os responsáveis fora dessas áreas. Tanto para homens quanto para mulheres, as taxas de alfabetização 
ficam em torno de $60 \%$ na área rural e $80 \%$ na área urbana, quase dez pontos percentuais abaixo, em média, dos responsáveis por domicílio em nível nacional ou nos municípios em que os TQs estão localizados.

Tabela 2 - Taxas de alfabetização das pessoas responsáveis pelo domicilio. Territórios Quilombolas, Brasil e municípios selecionados, rural/urbano, 2010

\begin{tabular}{ccccccc}
\hline & \multicolumn{2}{c}{ Territórios Quilombolas } & \multicolumn{2}{c}{ Brasil } & \multicolumn{2}{c}{ Municípios } \\
\cline { 2 - 6 } & Masculino & Feminino & Masculino & Feminino & Masculino & Feminino \\
\hline RURAL & $59,0 \%$ & $62,2 \%$ & $66,0 \%$ & $69,7 \%$ & $66,8 \%$ & $68,1 \%$ \\
URBANO & $78,9 \%$ & $80,7 \%$ & $88,8 \%$ & $92,1 \%$ & $93,2 \%$ & $95,1 \%$ \\
Total & $62,0 \%$ & $64,3 \%$ & $86,7 \%$ & $88,2 \%$ & $92,1 \%$ & $92,9 \%$ \\
\hline
\end{tabular}

Fonte: Banco de dados TQ do CEM/CEBRAP e CPEI-NEPO/UNICAMP com base no Censo Demográfico 2010 do IBGE. (Arruti; Dowbor, 2013)

Enfim, dessa breve observação dos dados sobre alfabetização quilombola, duas informações são absolutamente relevantes. A primeira delas é que a desvantagem educacional quilombola não pode ser atribuída nem genericamente à sua situação rural, nem particularmente à situação dos municípios em que os territórios se encontram, pois os dados do nosso universo de pesquisa indicam uma desvantagem relativa, para a população quilombola, que é coincidente com os limites dos seus próprios territórios. A segunda delas é que os nossos dados também apontam que tal desvantagem não vem sendo desfeita ou atenuada pelos últimos avanços no processo de escolarização nacional, na medida em que a situação de escolarização precária da população quilombola acima dos dez anos é reproduzida na faixa inferior, dos cinco aos nove anos.

\subsection{Escolas quilombolas}

Apesar de os números do Censo Escolar não nos oferecerem uma visão precisa das chamadas "escolas quilombolas", eles nos oferecem alguns indicativos importantes. Uma primeira consideração sobre esses números diz respeito à extensão e à importância que tal categoria vem assumindo em tão pouco tempo na reflexão sobre a situação escolar brasileira, comparável e potencialmente mais relevante, em termos numéricos, àquela relativa às escolas indígenas.

Até poucos anos atrás, as escolas indígenas destacavam-se como o setor da população brasileira com maior crescimento na oferta de educação escolar: um crescimento de $42 \%$ no número de escolas e quase $49 \%$ no número de matrículas 
entre 2002 e 2006 (716 novas escolas e 57.084 matrículas a mais). Essa expansão, próxima dos $10 \%$ ao ano, está ligada tanto à estabilização e à recuperação do crescimento populacional dos povos indígenas no Brasil, que alcançaram uma taxa de crescimento próxima dos $4 \%$ (a média nacional para o mesmo período foi de $1,4 \%$ ), quanto aos efeitos de uma política de promoção da educação indígena, que se expressa no incentivo à formação de professores indígenas em nível médio por meio das chamadas "licenciaturas interculturais" (que formaram, nos últimos dez anos, cerca de 9.100 professores indígenas em quase todos os estados do Brasil), assim como nos investimentos do FNDE em construção, reforma e ampliação de escolas indígenas. Acrescentam-se a isso programas especiais, como o Programa da Merenda Escolar, que atribui às escolas indígenas um valor per capita superior ao das escolas não-indígenas.

Tabela 3 - Brasil e grandes regiões, 2004-2015: número de estabelecimentos escolares classificados como indígenas ${ }^{17}$

\begin{tabular}{lccccccc}
\hline Região & $\mathbf{2 0 0 4}$ & $\mathbf{2 0 0 6}$ & $\mathbf{2 0 0 8}$ & $\mathbf{2 0 1 0}$ & $\mathbf{2 0 1 2}$ & $\mathbf{2 0 1 4}$ & $\mathbf{2 0 1 5}$ \\
\hline Norte & 1398 & 1529 & 1677 & 1761 & 1830 & 1966 & 1972 \\
Nordeste & 476 & 501 & 569 & 584 & 605 & 597 & 616 \\
Sudeste & 42 & 50 & 63 & 83 & 71 & 67 & 70 \\
Sul & 109 & 110 & 132 & 146 & 159 & 164 & 162 \\
Centro-Oeste & 208 & 233 & 257 & 315 & 289 & 249 & 254 \\
Brasil & 2233 & 2423 & 2698 & 2889 & 2954 & 3043 & 3074 \\
\hline
\end{tabular}

Fonte: MEC/Inep/Deed

A novidade da leitura dos dados da última década, porém, é o crescimento das escolas e das matrículas quilombolas. Inexistentes em 2003, depois que surgiram, no Censo Escolar de 2004, em número de 298, elas cresceram quase 250\% em dois anos e seguiram crescendo vigorosamente nos anos seguintes, ainda que em um ritmo bem menor e muito irregular. Medindo esse crescimento a cada dois anos, ficamos com a seguinte progressão em números aproximados: $35,5 \%$

17 Apenas estabelecimentos em atividade. O mesmo estabelecimento pode oferecer mais de uma etapa/modalidade de ensino. Nesta tabulação, considerou-se conjuntamente "terra indígena" e "unidade de uso sustentável em terra indígena”. Observa-se que, em 2014, dos 191.583 estabelecimentos em atividade, em 2.101 casos, o estabelecimento não foi classificado quanto a estar ou não localizado em terra indígena ou quilombo. Em 2015, todos os 188.689 estabelecimentos em atividade foram classificados quanto a ter ou não esta localização diferenciada. 
até $2008,13,55 \%$ até $2010,4,5 \%$ até 2012 e 21,5\% até $2014 .{ }^{18}$ Da mesma forma, as cerca de 22.800 matrículas quilombolas de 2004 crescem cerca de 23,3\% nos dois anos seguintes (alcançando pouco mais de 75.300 alunos matriculados em 2006), para, em seguida, atenuarem a curva de crescimento. Tal crescimento - isso deve ficar claro - é muito diferente do crescimento das escolas e das matrículas indígenas. Em primeiro lugar, ele não decorre de um crescimento vegetativo da população quilombola, mas da sua visibilização social e política. É na medida em que o tema ganha legitimidade nacional e é capaz de informar gestores dos rincões mais distantes, assim como é na medida em que as comunidades vão sendo reconhecidas oficialmente não só pelo governo federal, mas também pela sociedade circundante (o que pode acontecer antes ou depois do reconhecimento oficial), que os gestores das escolas situadas nessas comunidades vão também se convencendo da necessidade de classificá-las como escolas "situadas em área de quilombo".

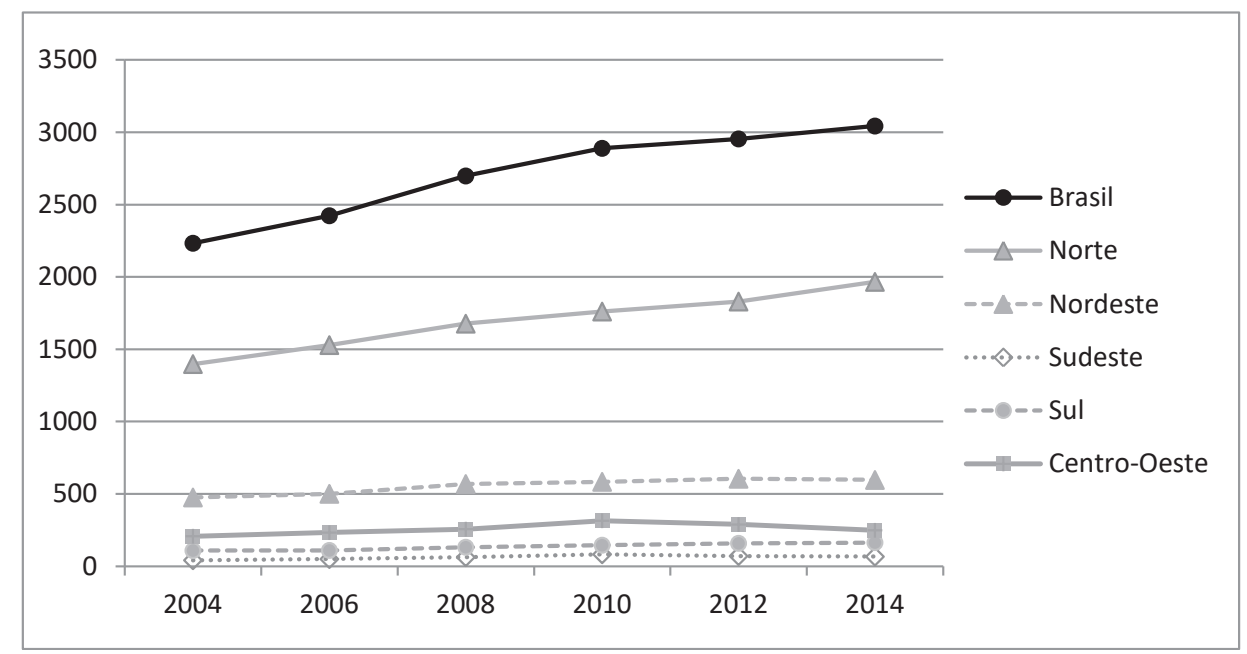

Gráfico 1 - Brasil e grandes regiões, 2004-2014: Evolução do número de escolas indígenas (estabelecimentos de Educação Básica)

Fonte: MEC/Inep/Deed.

18 A grande novidade dos dados a que acabamos de ter acesso foi a negativação desse crescimento de 2014 para 2015 (menos 2,6\%), que ainda não tivemos a oportunidade de interpretar. 
Tabela 4 - Brasil e grandes regiões, 2004-2015: número de estabelecimentos escolares classificados como em área de quilombo ${ }^{19}$

\begin{tabular}{lccccccc}
\hline Região & $\mathbf{2 0 0 4}$ & $\mathbf{2 0 0 6}$ & $\mathbf{2 0 0 8}$ & $\mathbf{2 0 1 0}$ & $\mathbf{2 0 1 2}$ & $\mathbf{2 0 1 4}$ & $\mathbf{2 0 1 5}$ \\
\hline Norte & 95 & 253 & 311 & 346 & 348 & 392 & 347 \\
Nordeste & 173 & 705 & 1038 & 1229 & 1276 & 1604 & 1623 \\
Sudeste & 48 & 213 & 200 & 208 & 232 & 282 & 262 \\
Sul & 5 & 23 & 59 & 58 & 54 & 62 & 69 \\
Centro-Oeste & 43 & 89 & 78 & 71 & 87 & 89 & 65 \\
Brasil & 364 & 1243 & 1686 & 1912 & 1997 & 2429 & 2366 \\
\hline
\end{tabular}

Fonte: MEC/Inep/Deed

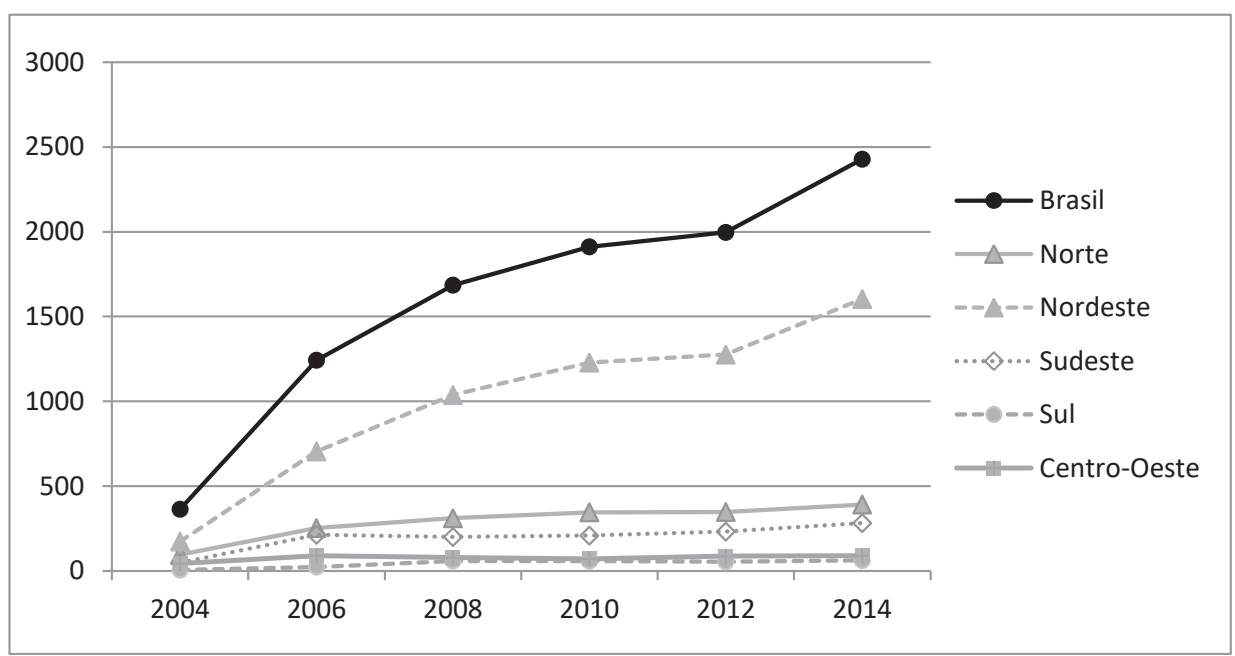

Gráfico 2 - Brasil e grandes regiões, 2004-2014: Evolução do número de escolas quilombolas (estabelecimentos de Educação Básica)

Fonte: MEC/Inep/Deed.

19 Apenas estabelecimentos em atividade. O mesmo estabelecimento pode oferecer mais de uma etapa/modalidade de ensino. Nesta tabulação, considerou-se conjuntamente "área remanescente de quilombos" e "unidade de uso sustentável em área remanescente de quilombo". Observa-se que, em 2014, dos 191.583 estabelecimentos em atividade, em 2.101 casos, o estabelecimento não foi classificado quanto a estar ou não localizado em terra indígena ou quilombo. Em 2015, todos os 188.689 estabelecimentos em atividade foram classificados quanto a ter ou não esta localização diferenciada. 
Outras considerações decorrem da comparação entre o número de escolas quilombolas, indígenas e rurais ${ }^{20}$ ao longo do tempo e conforme a sua distribuição pelas unidades da federação. Os três quadros que se seguem nos ajudam a perceber as diferenças entre estas categorias de escolas do campo. A presença das escolas rurais é generalizada pelos diferentes estados da federação, ainda que com concentrações destacadas em alguns estados (BA, MA, PA, MG, PE, CE e PI, nesta ordem de importância), enquanto as escolas indígenas apresentam uma fortíssima concentração nos estados ao Norte do país (AM, RO e MA), seguida de alguns estados com uma importância de segunda ordem (MT, PE, PA). Comparadas com estes dois casos, as escolas quilombolas tiveram grande crescimento em um número reduzido de estados (MA, PA, MG e BA), mas isso não aponta para uma concentração regional clara. Nota-se ainda que, no período em questão, o Censo Escolar registrou uma redução do número das escolas ditas rurais, decorrência de uma política mais ampla de implantação das "escolas nucleadas". ${ }^{21}$ O interessante é que, nesse contexto de drástica redução das escolas rurais, a reclassificação de parte delas como "localizadas em áreas quilombolas" pode estar desempenhando um efeito de resistência a tal política, percebida como negativa por estar sendo implantada sem qualquer diálogo com as comunidades e sem ter em conta seus custos sociais:

Todo esse quadro se agravou com os problemas provocados pelo transporte escolar do campo para o campo, mas acima de tudo do campo para a cidade. Se tudo isso não fosse o bastante, muitos municípios, alegando o elevado custo do transporte escolar, deixaram de cumprir as exigências mínimas de duração do ano letivo - 200 dias e 800 horas de efetivo trabalho escolar, com o retardamento do início ou a antecipação do término das aulas (MEC, 2007).

20 Estamos seguindo aqui as categorias utilizadas no Censo Escolar, mas reservaremos a categoria "escola rural" para designar o conjunto de escolas rurais, exceto as indígenas e quilombolas.

21 O processo de nucleação das escolas rurais começou, no Brasil, na década de 1970, nos estados das regiões Sul e Sudeste. Baseados no modelo norteamericano, o processo de nucleação consistia em reunir várias escolas ou salas ditas "isoladas", que foram fechadas ou desativadas, agrupando-as em uma única escola nos distritos ou em comunidades que reunissem maior número de pequenas comunidades em seu entorno, surgindo o modelo de organização conhecido como escola nucleada (MEC, 2007) 
Tabela 5 - Brasil e grandes regiões, 2004-2015: número de estabelecimentos escolares em área rural ${ }^{22}$

\begin{tabular}{lccccccc}
\hline Região & $\mathbf{2 0 0 4}$ & $\mathbf{2 0 0 6}$ & $\mathbf{2 0 0 8}$ & $\mathbf{2 0 1 0}$ & $\mathbf{2 0 1 2}$ & $\mathbf{2 0 1 4}$ & $\mathbf{2 0 1 5}$ \\
\hline Norte & 19363 & 18144 & 17432 & 16634 & 15952 & 15100 & 14753 \\
Nordeste & 57172 & 52928 & 49741 & 45431 & 41927 & 37599 & 35653 \\
Sudeste & 12316 & 11212 & 10508 & 9413 & 8813 & 8082 & 7678 \\
Sul & 8863 & 7596 & 6834 & 6022 & 5604 & 5141 & 4965 \\
Centro-Oeste & 2643 & 2292 & 2062 & 1888 & 1816 & 1758 & 1718 \\
Brasil & 100357 & 92172 & 86577 & 79388 & 74112 & 67680 & 64767 \\
\hline
\end{tabular}

Fonte: MEC/Inep/Deed

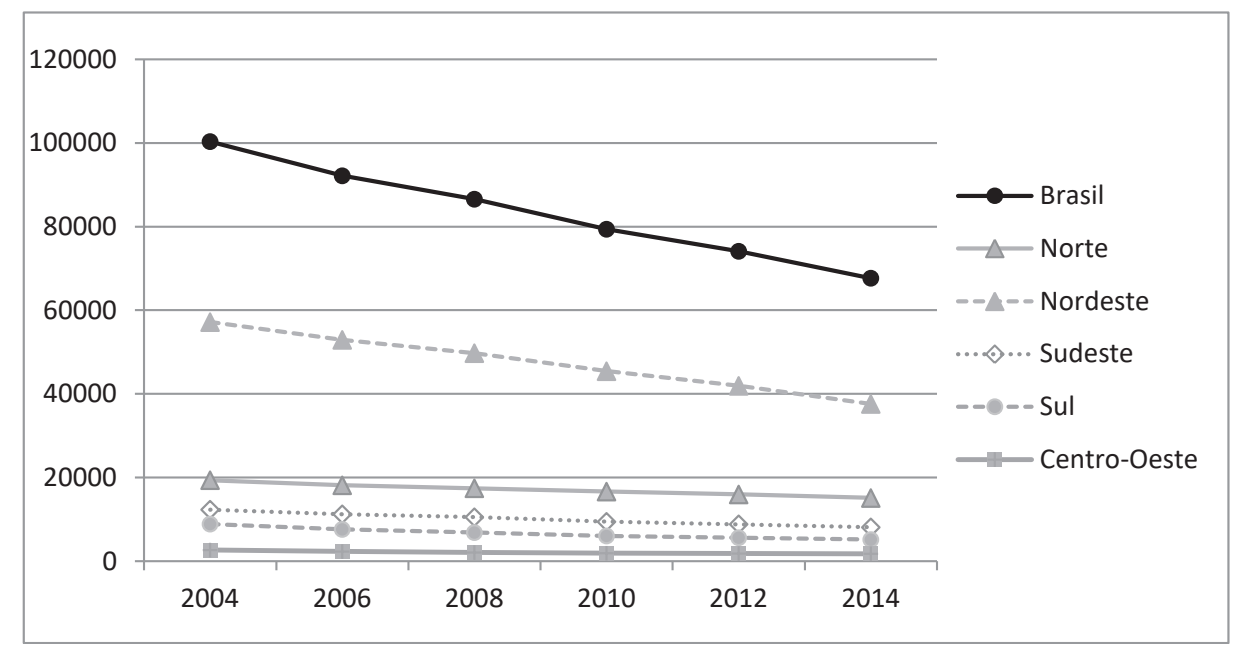

Gráfico 3 - Brasil e grandes regiões, 2004-2014: Evolução do número de escolas rurais

Fonte: MEC/Inep/Deed.

Como se vê na Tabela 5 e no Gráfico 3, a redução das escolas rurais é uma tendência em todas as regiões, mas a curva descendente nas regiões Norte e Nordeste, justamente onde se concentra o maior número de escolas indígenas e quilombolas, é mais acentuada. No quadro a seguir, buscamos identificar o crescimento e decrescimento anual dessas três categorias, ficando evidente o impulso na criação das escolas quilombolas, que arrefece a partir de 2010, para ficar no mesmo nível de crescimento das escolas indígenas.

22 Apenas estabelecimentos em atividade. O mesmo estabelecimento pode oferecer mais de uma etapa/modalidade de ensino 
Tabela 6 - Brasil, 2004-2015: crescimento percentual do número de escolas rurais

\begin{tabular}{lccccc}
\hline & $\mathbf{2 0 0 4 - 2 0 0 6}$ & $\mathbf{2 0 0 6 - 2 0 0 8}$ & $\mathbf{2 0 0 8 - 2 0 1 0}$ & $\mathbf{2 0 1 0 - 2 0 1 2}$ & $\mathbf{2 0 1 4 - 2 0 1 5}$ \\
\hline Indígena & 7,7 & 9,2 & 4,3 & 4,2 & 3,8 \\
Quilombola & 72,2 & 26,1 & 12,6 & 4,6 & 10,2 \\
Rural étnica & 28,7 & 15,5 & 7,5 & 4,4 & 8,5 \\
Rural não-étnica & $-10,4$ & $-7,6$ & $-10,1$ & $-7,9$ & $-1,5$ \\
Total rural & $-8,2$ & $-6,1$ & $-8,3$ & $-6,6$ & $-4,3$ \\
\hline
\end{tabular}

Fonte: MEC/Inep/Deed

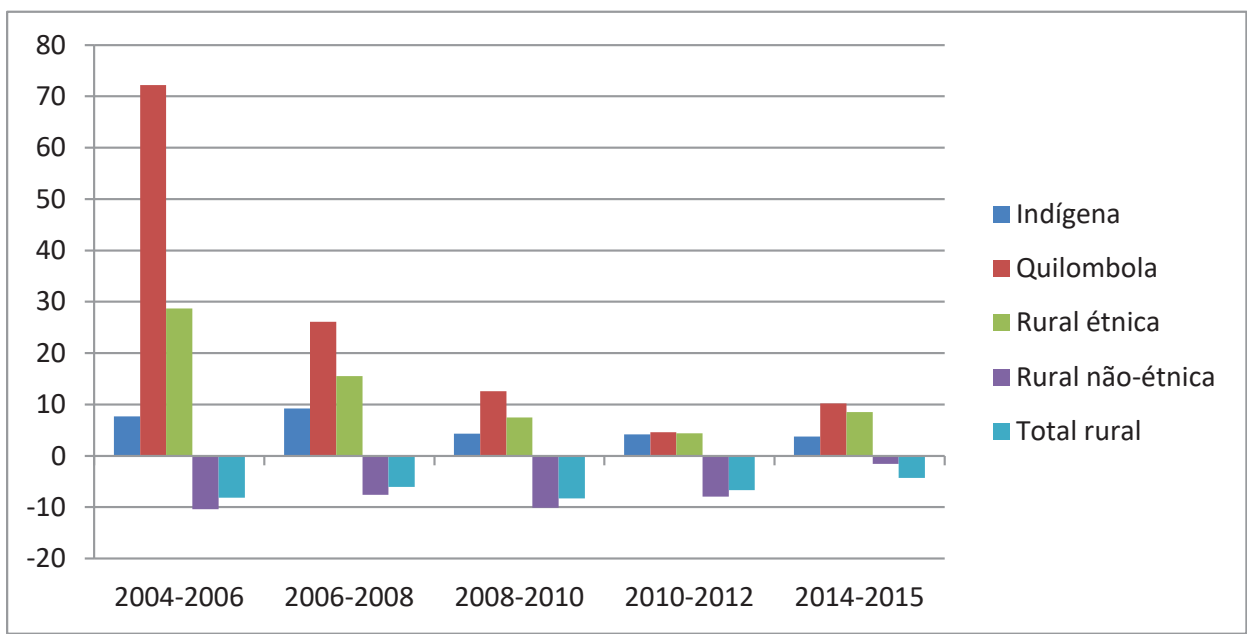

Gráfico 4 - Brasil, 2004-2015: evolução comparativa do número de escolas indígenas e quilombolas rurais e total das rurais (\%) Fonte: MEC/Inep/Deed.

Identificado o crescimento real e relativo de escolas quilombolas com relação às escolas indígenas e rurais em geral, desde 2004, é possível introduzir alguns dados que permitem uma aproximação, em termos muito gerais, de como tal crescimento tem respondido à demanda educacional dessas comunidades. Para isso, apresentaremos, nas tabelas a seguir, os números médios de matrículas de estudantes quilombolas por escola, assim como o número de escolas quilombolas em relação ao número de comunidades quilombolas certificadas (portanto, oficialmente reconhecidas como objeto de políticas públicas, entre elas a de escolarização), nos diferentes estados. As médias de matriculas por escola e as médias de escolas por comunidades certificadas resumidas nos dois quadros que se seguem às tabelas podem servir à construção de um indicador da demanda que a política de educação para comunidades quilombolas ainda deve suprir. 
Tabela 7 - Brasil, 2015: número de matrículas e de escolas em áreas remanescentes de quilombos por estado e região

\begin{tabular}{|c|c|c|c|}
\hline Unidade da federação & Matrículas & Escolas & Média de matrículas por escola \\
\hline RO & 155 & 4 & 39 \\
\hline $\mathrm{AC}$ & 0 & 0 & 0 \\
\hline AM & 616 & 5 & 123 \\
\hline $\mathrm{RR}$ & 0 & 0 & 0 \\
\hline $\mathrm{PA}$ & 31053 & 285 & 109 \\
\hline $\mathrm{AP}$ & 3815 & 28 & 136 \\
\hline TO & 2926 & 25 & 117 \\
\hline Norte & 38565 & 347 & 111 \\
\hline MA & 77488 & 741 & 105 \\
\hline PI & 6547 & 64 & 102 \\
\hline $\mathrm{CE}$ & 5913 & 38 & 156 \\
\hline $\mathrm{RN}$ & 2275 & 17 & 134 \\
\hline $\mathrm{PB}$ & 5683 & 31 & 183 \\
\hline $\mathrm{PE}$ & 13460 & 89 & 151 \\
\hline $\mathrm{AL}$ & 9021 & 36 & 251 \\
\hline SE & 8185 & 32 & 256 \\
\hline $\mathrm{BA}$ & 86116 & 575 & 150 \\
\hline Nordeste & 214688 & 1623 & 132 \\
\hline MG & 16658 & 176 & 95 \\
\hline ES & 2236 & 27 & 83 \\
\hline RJ & 9110 & 34 & 268 \\
\hline SP & 1607 & 25 & 64 \\
\hline Sudeste & 29611 & 262 & 113 \\
\hline PR & 1457 & 8 & 182 \\
\hline SC & 382 & 7 & 55 \\
\hline RS & 8473 & 54 & 157 \\
\hline Sul & 10312 & 69 & 149 \\
\hline MS & 939 & 6 & 157 \\
\hline MT & 4589 & 18 & 255 \\
\hline GO & 5365 & 41 & 131 \\
\hline DF & 0 & 0 & 0 \\
\hline Centro-Oeste & 10893 & 65 & 168 \\
\hline Brasil & 304069 & 2366 & 129 \\
\hline
\end{tabular}

Fonte: MEC/Inep/Deed 


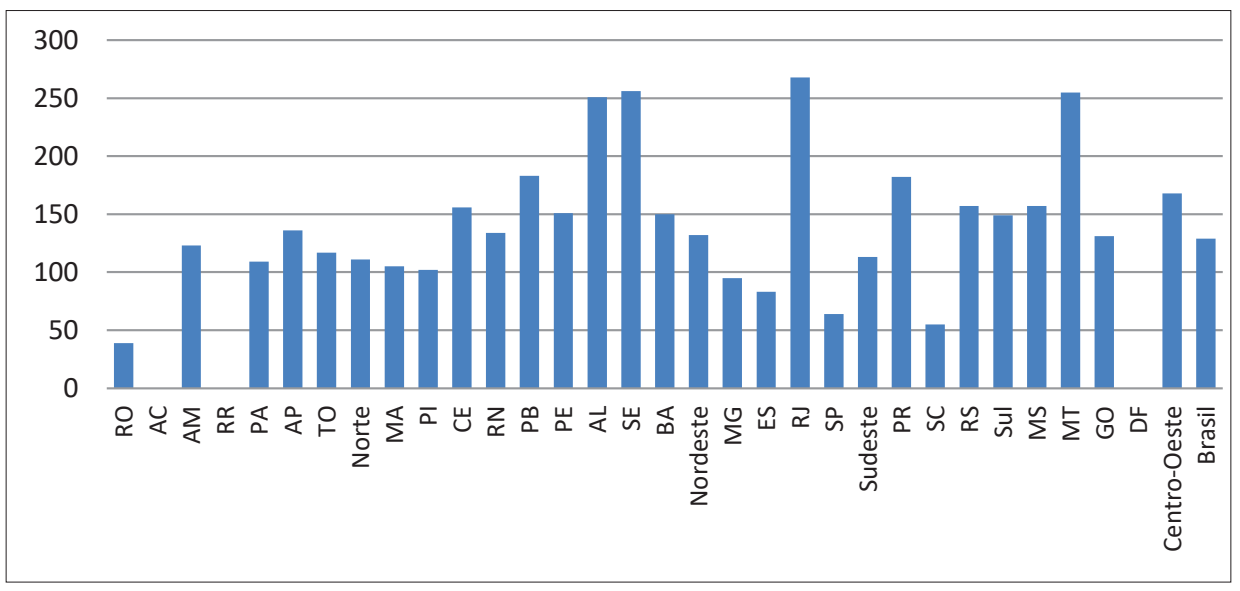

Gráfico 5 - Brasil, 2015: média de matrículas por escola em áreas remanescente de quilombos por estado e região

Fonte: MEC/Inep/Deed

É interessante notar que as médias regionais não variam muito (médias de 111 a 168 alunos por escola), contra uma variação muito significativa, se a comparação for por unidades da federação. Assim, contra uma média nacional de 129 alunos por escola, os pontos extremos, na comparação, são ocupados, de um lado, pelos estados de Rondônia e de Santa Catarina (com respectivamente 39 e 55 de matriculas em média por escola) e, por outro lado, pelos estados do Mato Grosso, de Sergipe e do Rio de Janeiro (respectivamente com 255, 256 e 268 de matriculas, em média, por escola). A situação das comunidades quilombolas do Rio de Janeiro, diante de intensos processos de urbanização, certamente é um caminho para explicar tal concentração. ${ }^{23}$

No Gráfico 6, estabelecemos a relação entre o número de escolas e o número de comunidades certificadas em cada estado como uma forma de nos aproximarmos de uma estimativa sobre como a demanda por educação tem sido respondida. Mais uma vez, é preciso todo cuidado ao realizarmos a leitura desses números, já que ainda não foi possível verificar a coincidência da localização efetiva dessas escolas e das comunidades certificadas. Portanto, o que demonstramos é apenas uma correlação quantitativa e, mesmo que o índice seja um, a situação estadual pode estar repleta de desigualdades internas, com comunidades

23 Isso se aplica não tanto no caso das diminutas comunidades situadas no município sede (Sacopã e Pedra do Sal), mas muito mais provavelmente no caso das comunidades da região dos Lagos (Preto Forro, Caveira, Botafogo), que, além de serem maiores e possuírem mais crianças e jovens, estão em uma área de nucleação das escolas. 
possuindo mais de uma escola contra outras destituídas de qualquer escola. Ainda assim, porém, tal correlação já nos é útil como indicador de uma falta generalizada: a grande maioria de estados tem menos de uma escola "localizada em áreas quilombola" por comunidade certificada, ficando apenas os estados do Pará, do Maranhão, do Rio de Janeiro e de Goiás com uma correlação positiva. Esse é um ponto de partida interessante para pensar a educação quilombola ainda no plano da redistribuição, que não deve estar separada dos avanços relativos à definição de uma educação diferenciada, que reconheça as particularidades dessas mesmas comunidades.

Tabela 8 - Número de escolas em áreas remanescentes de quilombos e de comunidades certificadas por estado e regiões

\begin{tabular}{|c|c|c|c|}
\hline $\begin{array}{l}\text { Unidade } \\
\text { da federação }\end{array}$ & $\begin{array}{l}\text { Comunidades } \\
\text { certificadas }\end{array}$ & Escolas & $\begin{array}{l}\text { Média de escolas } \\
\text { por comunidade }\end{array}$ \\
\hline RO & 7 & 4 & 0,57 \\
\hline $\mathrm{AC}$ & 0 & 0 & 0,00 \\
\hline $\mathrm{AM}$ & 5 & 5 & 1,00 \\
\hline $\mathrm{RR}$ & 0 & 0 & 0,00 \\
\hline $\mathrm{PA}$ & 218 & 285 & 1,31 \\
\hline $\mathrm{AP}$ & 33 & 28 & 0,85 \\
\hline TO & 37 & 25 & 0,68 \\
\hline Norte & 300 & 347 & 1,16 \\
\hline MA & 467 & 741 & 1,59 \\
\hline PI & 81 & 64 & 0,79 \\
\hline $\mathrm{CE}$ & 42 & 38 & 0,90 \\
\hline $\mathrm{RN}$ & 22 & 17 & 0,77 \\
\hline $\mathrm{PB}$ & 37 & 31 & 0,84 \\
\hline $\mathrm{PE}$ & 129 & 89 & 0,69 \\
\hline $\mathrm{AL}$ & 66 & 36 & 0,55 \\
\hline SE & 27 & 32 & 1,19 \\
\hline $\mathrm{BA}$ & 612 & 575 & 0,94 \\
\hline Nordeste & 1483 & 1623 & 1,09 \\
\hline MG & 220 & 176 & 0,80 \\
\hline ES & 34 & 27 & 0,79 \\
\hline RJ & 32 & 34 & 1,06 \\
\hline SP & 51 & 25 & 0,49 \\
\hline Sudeste & 337 & 262 & 0,78 \\
\hline PR & 37 & 8 & 0,22 \\
\hline
\end{tabular}




\begin{tabular}{lccc}
\hline $\begin{array}{l}\text { Unidade } \\
\text { da federação }\end{array}$ & $\begin{array}{c}\text { Comunidades } \\
\text { certificadas }\end{array}$ & Escolas & $\begin{array}{c}\text { Média de escolas } \\
\text { por comunidade }\end{array}$ \\
\hline SC & 13 & 7 & 0,54 \\
RS & 107 & 54 & 0,50 \\
Sul & 157 & 69 & 0,44 \\
MS & 22 & 6 & 0,27 \\
MT & 67 & 18 & 0,27 \\
GO & 28 & 41 & 1,46 \\
DF & 0 & 0 & 0,00 \\
Centro-Oeste & 117 & 65 & 0,56 \\
Brasil & 2394 & 2366 & 0,99 \\
\hline
\end{tabular}

Fonte: MEC/Inep/Deed para os dados sobre escolas. Censo Escolar 2015. Fundação Cultural Palmares para os dados sobre comunidades quilombolas certificadas (2014).

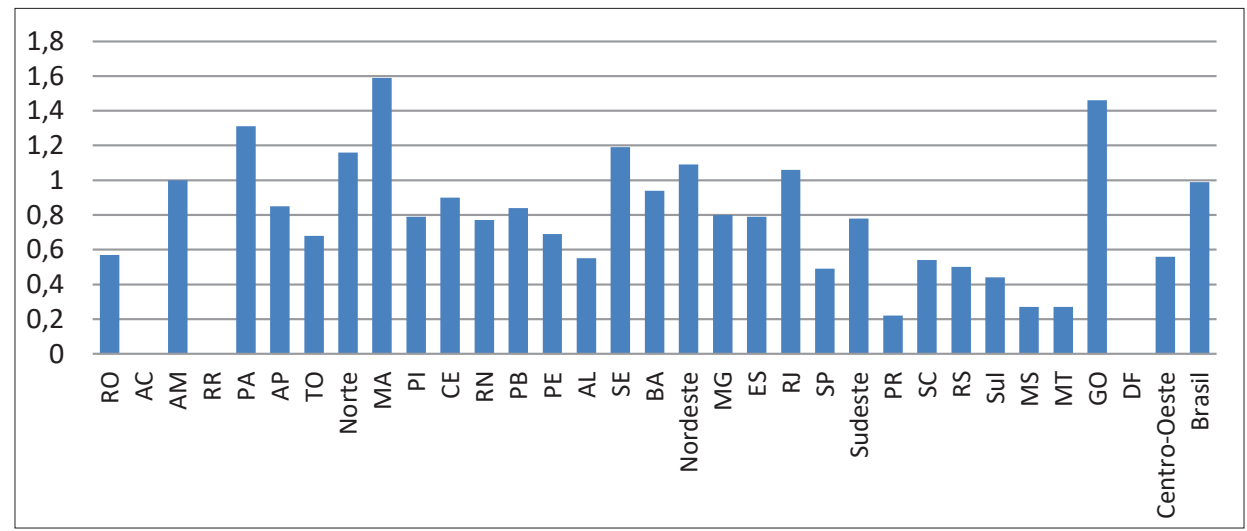

Gráfico 6 - Média de escolas por comunidade certificadas por estudo e regiões (2014-2015)

Fonte: MEC/Inep/Deed para os dados sobre escolas. Censo Escolar 2015.

Fundação Cultural Palmares para os dados sobre comunidades quilombolas certificadas (2014).

\section{Considerações finais}

Como dissemos nas primeiras linhas deste texto, a educação quilombola, assim como o próprio quilombo, são objetos em construção, dos quais não é possível falar senão percorrendo os caminhos da controvérsia pública em torno da sua enunciação e das disputas em torno dos conceitos e números que definirão os limites do fenômeno. Não se trata de falar tão só e puramente de uma realidade, mas também dos modos de enunciar este mundo, o que significa definir o tanto 
de realidade que caberá nos conceitos, o que será iluminado ou encoberto pelo modo como nós os enunciamos.

Fizemos referência, muito rapidamente, a como a ressemantização do quilombo, tendo por referência um fenômeno histórico colonial e imperial, permitiu iluminar uma realidade que permanecia invisível: a realidade das comunidades negras tradicionais. Vimos que tal visibilidade permitiu a criação de um movimento social novo, o movimento quilombola, que, por sua vez,deu novo sentido - ou também ressemantizou - as lutas históricas travadas por essas comunidades: depois de abrigadas e visibilizadas por outras categorias de classificação e de atribuição de direitos, ao se reconhecerem como quilombolas, elas alteraram a percepção que têm de suas próprias lutas. Isso vale também para o conceito de educação quilombola, que ilumina um campo de afirmação de direitos novo para tais comunidades. Mesmo no caso das comunidades que trabalharam arduamente para construir prédios e contratar professores com seus próprios e parcos recursos, tendo em vista oferecer educação formal a suas crianças e jovens, a luta pela educação não era mediada pela ideia, agora disponível, de que a educação não precisa operar como uma autonegação da sua origem, da sua cor, do seu modo de falar, de seu modo de existência rural, de sua religiosidade, de seus modos de organizar, casar e trabalhar ou de suas demandas territoriais. A ideia de uma educação quilombola transforma e amplia o campo de possibilidades aberto pela educação para essas comunidades.

Entretanto, isso também acontece com as próprias instituições estatais, que, ao produzirem as ações destinadas às escolas e aos professores quilombolas, em lugar de apenas "capacitarem" o seu público, qualificam-se elas mesmas no tema. No caso da Bahia, por exemplo, estudado por Noronha (2013), os cursos de formação para professores e lideranças quilombolas organizados pela Secretaria de Educação do estado foram importantes não só para a troca de informações e de conhecimentos entre professores, lideranças e pesquisadores, mas também para a formulação das próprias demandas, por parte das comunidades quilombolas, assim como para a elaboração de um conhecimento mínimo dos técnicos da secretaria sobre os contextos nos quais deveriam intervir. Como chama atenção o autor, esse é um exemplo de como a construção de uma política não é apenas a definição de um conjunto de iniciativas por parte do Estado, tendo em vista objetivos e metas, mas também pode ser, ela mesma, um processo pedagógico: o diálogo com as populações que não tiveram acesso à educação escolar acaba por orientar a proposição de formas inovadoras de se fazer escola, assim como a 
reorganização do próprio Estado, por meio da criação de coordenações, secretarias, grupo intersetorial, conselhos, fóruns etc.

Finalmente, a leitura dos números relativos à alfabetização quilombola, por mais cuidadosos que tenhamos que ser na sua abordagem, e dos dados sobre alfabetização nos territórios das comunidades tituladas (e, por isso, em princípio, privilegiadas pelas políticas públicas) são suficientes para chamar a atenção sobre como esta população representa o setor mais desfavorecido, do ponto de vista da oferta educacional, mesmo diante de sua expansão recente. Eles nos obrigam a reconhecer que o tema da educação, ao lado da terra, é também prioritário. Mesmo que nos restringíssemos ao debate relativo à expansão da escola regular (sem qualquer preocupação com uma educação diferenciada), a discriminação estrutural incidente sobre essa parcela da população não seria percebida e documentada sem o recurso à categoria de quilombos - que recorta com precisão uma exclusão antes apenas difusa.

Os mesmos dados que apontam para um crescimento das escolas quilombolas, na região Nordeste, comparável com o crescimento das escolas indígenas na região Norte, deixam evidentes os limites dessa expansão: o que, em princípio, poderia parecer um crescimento surpreendente, mostra-se fruto, em grande parte, de uma simples reclassificação das escolas rurais convencionais, que vêm desaparecendo em um ritmo muito maior por meio do processo de nucleação. Ainda que tal reclassificação possa desempenhar o papel positivo de operar como uma resistência à política de nucleação, está claro que ela não corresponde a uma preparação dessas escolas para os novos desafios que lhe são propostos pela ideia de uma educação diferenciada para a população quilombola.

Enfim, a análise da correlação entre conceitos, normas e números nos abre uma pauta extensa de reflexão sobre o fenômeno, em sua dimensão estrutural, que dificilmente é revelada pelas descrições etnográficas de situações escolares e de processos de construção de políticas públicas estaduais, ainda que precisem destes para qualificar sua interpretação.

\section{Nota metodológica}

As informações oficiais disponíveis sobre comunidades quilombolas não estão unificadas, não partem das mesmas estimativas ou modos de contabilizar sua população, nem constituem sempre banco de dados acessíveis. As suas principais fontes são, hoje, o livro de certificações da Fundação Cultural Palmares, o 
cadastro de Territórios Quilombolas em processo de regularização fundiária do INCRA e o Censo Escolar Quilombola. Recentemente, a SEPPIR constituiu um Sistema de Monitoramento dos Territórios Quilombolas (http://monitoramento.seppir.gov.br/), que reúne dados do INCRA e de institutos estaduais de terra e que tem o mérito de juntar gráficos com os números totais de certificações e titulações por UF e por data, com fichas individuais das comunidades, nas quais constam os territórios, projetados em mapas de satélite, mas cujo uso para pesquisa é extremamente limitado. O SMTQ não nos dá acesso direto aos dados que alimentam seus gráficos (disponíveis nos sites do INCRA e de uma parte dos Institutos Estaduais de Terras apenas em formato .pdf), nem nos oferece uma nota metodológica que explique algumas lacunas importantes, já que algumas comunidades já tituladas há anos não constam em seus dados. A contagem da população tem alguns inconvenientes importantes: ela é contabilizada por unidades familiares, e as famílias contadas são apenas as cadastradas pelo Incra - devemos considerar que, em algumas comunidades, não temos famílias cadastradas. Enfim, o SMTQ é uma ferramenta com potencial uso pedagógico, muito útil para o uso escolar, por exemplo, mas não foi pensada como um sistema de acesso aos dados de caráter científico.

Por serem temáticas, essas fontes de informação não são flexíveis como o censo demográfico, que, por sua vez, impõe-nos o obstáculo de não incluir entre as suas categorias de auto-atribuição a de quilombola. Como forma de contornar essa dificuldade, o projeto "Desigualdades étnico-raciais no Brasil: análise dos povos indígenas e das comunidades quilombolas" (2013-2015) elaborou uma estratégia metodológica na qual cruzamos as informações de localização dos territórios quilombolas oficialmente reconhecidos e titulados (e que, portanto, já dispõem de uma delimitação geográfica oficial) com as informações levantadas pelo Censo Demográfico 2010 na escala dos setores censitários (as menores unidades disponíveis ao público em geral). Utilizamos, para isso, os "shapes" (mapas georreferenciados) existentes na base do INCRA relativos a 169 territórios titulados, completando-os com a reconstituição de outros poucos territórios por meio da produção de mais mapas a partir dos "memoriais descritivos" (dados sobre a localização e a natureza do terreno e indicações sobre suas coordenadas geográficas, em latitude e longitude) dos territórios publicados no Diário Oficial da União. O segundo passo da nossa estratégia metodológica consistiu, então, em sobrepor as áreas desses mapas a um banco nacional de setores censitários georreferenciados, construído pelo Centro de Estudos da Metrópole (CEM). 
É importante notar que esta solução metodológica é aproximativa, na medida em que a coincidência entre os territórios quilombolas e os setores censitários não é perfeita. O total da população negra contida nos setores censitários que sobrepusemos aos TQs estudados é de 146.926 pessoas, sendo 132.421 delas da zona rural e 14.505 da zona urbana. Este número, porém, não corresponde exatamente à quantidade de pessoas que vivem nas comunidades quilombolas, uma vez que cada setor censitário selecionado em nossa pesquisa pode incluir domicílios que estão fora dos TQs, ainda que se encontrem na proximidade. A validade dessa aproximação foi testada por variáveis georreferenciadas e censitárias. Entre elas, está a percentagem da população negra no interior de cada território selecionado, que se mostrou sempre mais alta que as proporções de negros no território nacional e nos municípios em que as comunidades quilombolas se localizam, o que indica que, apesar de não ser perfeita a sobreposição entre os setores censitários selecionados e os TQs reais, para a grande maioria dos casos, há enorme correspondência entre esses duas áreas. Enquanto, no total da população nacional, a proporção da população negra é de 50,8\%, nos setores censitários sobrepostos aos territórios quilombolas, ela é de 77,5\%. A maior porcentagem de negros nos setores censitários pertencentes aos TQs se mantém também quando comparados com a média dos municípios aos quais esses territórios pertencem $(51,1 \%)$.

Isso implicou a criação de um Banco de Dados Georreferenciado no qual buscamos ajustar os limites de 171 territórios quilombolas e dos agregados de setorescensitários que lhe são sobrepostos, de forma a isolar os dados relativos à população compreendida pela interseção de ambos. Desse esforço resultou o banco de dados mais completo disponível sobre população quilombola, no qual podemos cruzar dados censitários detalhados sobre cada território com aproximadamente 400 variáveis.

De qualquer forma, a leitura das análises realizadas precisa levar em consideração que estamos falando de uma parcela das comunidades quilombolas: 171 sobre um número indeterminado de comunidades existentes (que pode ir de 2.800 a cinco mil). Ainda assim, tal parcela permite aproximarmos nosso olhar sobre as condições de vida nos territórios reconhecidos pelo Estado como pertencentes a comunidades culturalmente distintas e que, a partir de 2003, seriam abrangidos pelas políticas sociais especificamente voltadas para elas.

O projeto "Desigualdades étnico-raciais no Brasil: análise dos povos indígenas e das comunidades quilombolas" (Arruti; Dowbor, 2013) surgiu da demanda e do financiamento iniciais da Christian Aid, sendo coordenado por José Maurício Arruti (CPEI e CERES/UNICAMP) e por Monika Dowbor (CEM/ 
CEBRAP), tendo como pesquisadores Alessandra Traldi Simoni e Bárbara Roberto Estanislau (CPEI e NEPO/UNICAMP), Ricardo de Sampaio Dagnino (NEPO/ UNICAMP), Danilo Torini (CEBRAP), Daniel Waldvogel e Donizete Cazolato (CEM), e por consultora Marta Maria do Amaral Azevedo (NEPO/UNICAMP).

\section{Referências}

ASSOCIAÇÃO BRASILEIRA DE ANTROPOLOGIA - ABA. Documento do Grupo de Trabalho sobre Comunidades Negras Rurais (Rio de Janeiro, 17-18 de outubro de 1994). Boletim Informativo NUER - Núcleo de Estudos sobre Identidade e Relações Interétnicas / Fundação Cultural Palmares - v. 1, Florianópolis: UFSC, 1997, pp. 81-82. Disponível em: $<$ http://nuer.ufsc.br/files/2014/04/m-mgpefhgnff_boletim_nuer_1.pdf $>$. Acesso em: 30 out. 2014.

ARROYO, Miguel Gonzalez; CALDART, Roseli Salete; MOLINA, Mônica Castagna (Org.).Por uma educação do campo. 3. ed. Petrópolis, RJ: Vozes, 2008.

ARRUTI, José Maurício. “Quilombos”. In: Osmundo Pinho (org), Raça: Perspectivas Antropológicas. Salvador: ABA / Ed. Unicamp / EDUFBA, 2008.

ARRUTI, José Maurício; CAMPOS, Carla Siqueira. Notas sobre o Sul da Bahia. Boletim Territórios Negros v. 8, n. 34, maio/jun. 2008. Disponível em: < http://www.koinonia.org. br/comunicacao-periodicos_tn.asp?cod=39>. Acesso em: 30 out. 2014.

ARRUTI, José Maurício; Dowbor, Monica. Desigualdades étnicas no Brasil: análise das populações quilombola e indígena. CEBRAP/CPEI-NEPO-UNICAMP (inédito), 2013.

BRASIL. Lei no 9.394, de 20 de dezembro de 1996 que Estabelece as diretrizes e bases da educação nacional.. Diário Oficial da União, Brasília, 23 de dezembro de 1996, Seção I, p. 27833 a 27841.

BRASIL. CNE/CP Resolução 1/2004 institui as Diretrizes Curriculares Nacionais para a Educação das Relações Étnico-Raciais e para o Ensino de História e Cultura Afro-Brasileira e Africana. Diário Oficial da União, Brasília, 22 de junho de 2004, Seção 1, p. 11.

BRASIL. Plano Nacional de Implementação das Diretrizes Curriculares Nacionais para Educação das Relações Étnico-Raciais e para o Ensino de História e Cultura Afrobrasileira e Africana. Ministério da Educação, Secretaria de Educação Continuada, Alfabetização, Diversidade e Inclusão. Brasília: MEC, SECADI, 2013. 
BRASIL. Decreto ${ }^{\circ}$ 7.352, de 4 de novembro de 2010. Dispõe sobre a política de educação do campo e o Programa Nacional de Educação na Reforma Agrária - PRONERA. Diário Oficial da União - Seção 1 - 5/11/2010.

CARNEIRO, Édson. O quilombo dos Palmares. Rio de Janeiro: Companhia Nacional, 1988.

CENTRO DE CULTURA NEGRA - CCN. Sociedade Maranhense de Defesa dos Direitos Humanos - SMDDH. Projeto vida de negro: 10 de luta pela regularização e titulação das terras de preto do Maranhão. São Luís: Centro de Cultura Negra, 1998.

CONFERÊNCIA NACIONAL DE EDUCAÇÃO (CONAE). Construindo o Sistema Nacional articulado de Educação: o Plano Nacional de Educação, diretrizes e estratégias; Documento Final. Brasília, DF: MEC, 2010.

BRASIL. Decreto n 65.810, de 08 de dezembro de 1969. Promulga a Convenção Internacional sobre a Eliminação de todas as Formas de Discriminação Racial. Diário Oficial da União - Seção 1 - 10/12/1969.

FIGUEIREDO, André Videira de. O Caminho Quilombola: sociologia jurídica do reconhecimento étnico. Curitiba: Appris, 2011.

FRASER, Nancy. Justice interruptus: critical reflections on the "postsocialist" condition. Nova York; Londres: Routledge, 1997.

FREITAS, Décio. Palmares: a guerra dos escravos. Rio de Janeiro: Ed. Graal. 1990

GUIMARÃES, Antônio Sérgio Alfredo. Classes, raças e democracia. São Paulo: FUSP: Editora 34, 2002.

HASENBALG, Carlos. Discurso sobre a raça: pequena crônica de 1988. In: HASENBALG, Carlos; SILVA, Nelson do V. Relações raciais no Brasil contemporâneo. Rio de Janeiro: Rio Fundo: IUPERJ, 1992.

MINISTÉRIO DA EDUCAÇÃO - Secretaria de Educação Continuada, Alfabetização e Diversidade - SECAD. Consulta referente às orientações para o atendimento da Educação do Campo. RELATOR: Murílio de Avelar Hingel. PROCESSO No: 23001.000107/2007-28. PARECER CNE/CEB No: 23/2007.

MINISTÉRIO DA EDUCAÇÃO - Conselho Nacional de Educação Câmara de Educação Básica. Resolução No 4, DE 13 DE JULHO DE 2010. Define Diretrizes Curriculares Nacionais Gerais para a Educação Básica. Diário Oficial da União, Brasília, 14 de julho de 2010, Seção 1, 2010. 
MINISTÉRIO DA EDUCAÇÃO - MEC. CONSELHO NACIONAL DE EDUCAÇÃO CÂMARA DE EDUCAÇÃO BÁSICA RESOLUÇÃO No 8, DE 20 DE NOVEMBRO DE 2012. Resolução CNE/CEB 8/2012, que Define Diretrizes Curriculares Nacionais para a Educação Escolar Quilombola. Diário Oficial da União, Brasília, 21 de novembro de 2012, Seção 1, p. 26.

MOURA, Clovis. Rebeliões da senzala: quilombos, insurreições, guerrilhas. São Paulo: Conquista, 1972.

NASCIMENTO, Abadias do. O Quilombismo. Petrópolis: Vozes, 1980.

NORONHA, Suely. Diretrizes curriculares para a educação escolar quilombola: o caso da Bahia e o contexto nacional. Dissertação (Mestrado em Educação) - Departamento de Educação. Pontifícia Universidade Católica do Rio de Janeiro, 2013.

OLIVEIRA, Olívia Chaves de. As possibilidades de novos rumos para a educação formal na Ilha da Marambaia - RJ. Dissertação (Mestrado em Educação Agrícola)-Universidade Federal Rural do Rio de Janeiro, Rio de Janeiro, 2009.

OLIVEIRA, Waldir. Freitas. Apresentação. In: CORDEIRO, Edson. O Quilombo dos Palmares. 2. ed. Rio de Janeiro: Cia Ed. Nacional, 1988. (Brasiliana V. 302).

PALMARES FUNDAÇÃO CULTURAL. Quadro Geral De Comunidades Remanescentes de Quilombos (CRQs). 2014. Disponível em: <http://www.palmares.gov.br>. Acesso em: 30 out. 2014.

REIS, João José; GOMES, Flávio dos Santos. (Org.). Liberdade por um fio: história dos quilombos no Brasil. São Paulo: Cia das Letras, 1996.

SILVEIRA, Oliveira. Como surgiu o 20 de Novembro?. Thoth, n. 3, 1997.

Soares, Carlos Eugênio Líbano. Zungu: rumor de muitas vozes. Rio de Janeiro: Arquivo Público do Estado do Rio de Janeiro, 1998.

Submissão em: 09/05/2016.

Aprovação em: 23/05/2016. 